\title{
Spatial Aspects of University Graduates in Slovakia
}

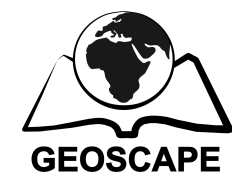

\author{
Oliver Rafaj ${ }^{1 *}$ - Štefan Rehák ${ }^{1}$ \\ ${ }^{1}$ Department of Public Administration and Regional Development, Faculty of National \\ Economy, University of Economics in Bratislava \\ *oliver.rafaj@gmail.com
}

\begin{abstract}
University and college graduates do not represent just a highly skilled workforce. They are holders of a high level of education and they serve also as a component of human capital that have a high potential for increase productivity, create new jobs and discover new innovative production processes. This contribution deals with the concentration and dispersion of the production of university and college graduates of master level studies in Slovak cities, as holders of a high level of human capital. Examined were 41 of 46 fields of master level studies, which were assigned to 6 groups of studies. Within the overall production of graduates, there was observed a dispersion of production, because during the observed time period, between 1997 and 2015, the competition between cities in generating graduates of master level studies has increased. Within the production of individual groups of studies, the evolution was not so clear. In some groups of studies, the production of master level graduates has concentrated over the observed period time, in other groups the production has dispersed and in one group of studies the situation has not changed.
\end{abstract}

Key words: regional development, universities, human capital, spatial concentration, cities, university graduates

\section{Highlights for public administration, management and planning:}

- The diversification of the production of university and college graduates in the country is recommended.

- Regional approach to innovations is suggested in order to reflect differences in the structure of graduates.

- The necessity to start to collect data on the migration of university graduates is urged.

Received: 1 Nov 2016 - Received in revised form 12 Dec 2016 - Accepted: 16 Dec 2016

\section{Introduction}

The current regional policy of the European Union, which came from the Europe 2020 strategy, targets all member regions and cities in order to support job creation, increase competitive business environment, start the economic growth, ensure sustainable development and improve the quality of life of their citizens. The role of European Union's regional policy is to reduce socio-economic disparities between regions and ensure their equitable development. One of many approaches that show the way to achieve designated objectives lies in building and developing human capital. Important role in creating and spreading forms of human capital play a variety of educational institutions, particularly universities and colleges. 
These institutions provide a high level of education, ensure the transfer of new knowledge into real world (e.g. spillover effects) and concentrate in a close proximity a large number of highly educated people. These facts were confirmed by a large number of expert studies and publications.

The aim of this paper was to examine the development of graduates of master level studies in Slovakia and clarify the concentration, respectively the dispersion of their production in Slovak cities. At the same time, there was an attempt to determine whether there is going on an increasing competition in production of university graduates between Slovak cities, or there is a monopolization of their production. The exploration of the evolution of university graduates and the concentration of their production was realized for aggregated, specialized groups of studies. The importance of this contribution lies in the fact, that the field of competitiveness of Slovak cities in producing university graduates has not yet been properly explored.

\section{Theoretical background}

John C. Scott points out in his contribution (Scott 2006) on various missions of universities that play in the economy. In connection with human capital he refers to universities in particular, as the centre that provide employment not only for university teachers and professors, but as well as for various specialized professions, with whom universities have built different business relations. Therefore, the significance of universities lies in the concentration of human capital and economic activities in the close proximity. In other studies (Hansen \& Lehman 2006; Huggins \& Jonston 2009 or Goldstein et al. 2011), authors highlight the major scientific and research activities of universities in spreading and enlarging knowledge in forms of getting new inventions, patents, technologies and their subsequent commercialization, from which benefit the whole society. Particular importance of colleges and universities lies in the production and dissemination of human capital as a factor for spatial development, through the production of college and university graduates. University graduates represent a highly skilled workforce, which is immediately after the successful completion of its study, available in the labour market. High level of education is the component of human capital that has a high potential for increase productivity, create new businesses and jobs, invent new products, introduce new innovations and production processes as well as many other activities that lead to securing sustainable development (Karlsson \& Zhang 2001). From a spatial point of view, universities and colleges are located mainly in cities and urbanised settlements, because on the one hand there are potential residents who want to raise their education levels and improve their positions in the labour market. And on the other there are firms that seek highly skilled labour power for their activities. For those reasons, universities located in cities affect the development of a much wider environment (Benneworth et al. 2010; Goddard \& Vallance 2013).

\section{Institutional framework}

After the year of 1990 a massive development of higher education occurred in Slovakia. According to Rehák et al (Rehák et al. 2015), the total number of university students in 2008 was three times bigger than in 1990. During that time period, there were created 20 new colleges and universities. This rapid growth has also manifested in the number of cities that were generating the higher education. According to data from the Centre of Scientific and Technical Information of Slovak Republic (CVTISR), in 1997 the master level studies were provided by 11 cities, while in 2015, graduates of master level studies were produced in 18 cities. During those 19 years it was possible to study the master level studiesin 20 cities (Badín', Banská Bystrica, Banská Štiavnica, Bratislava, Dubnica nad Váhom, Komárno, Košice, Liptovský Mikuláš, Martin, Nitra, Prešov, Púchov, Ružomberok, Skalica, Sládkovičovo, Spišské Podhradie, Trenčín, Trnava, Zvolen, Žilina). The expansion of the number of cities which provided the level of master studies offers Figure 1. 


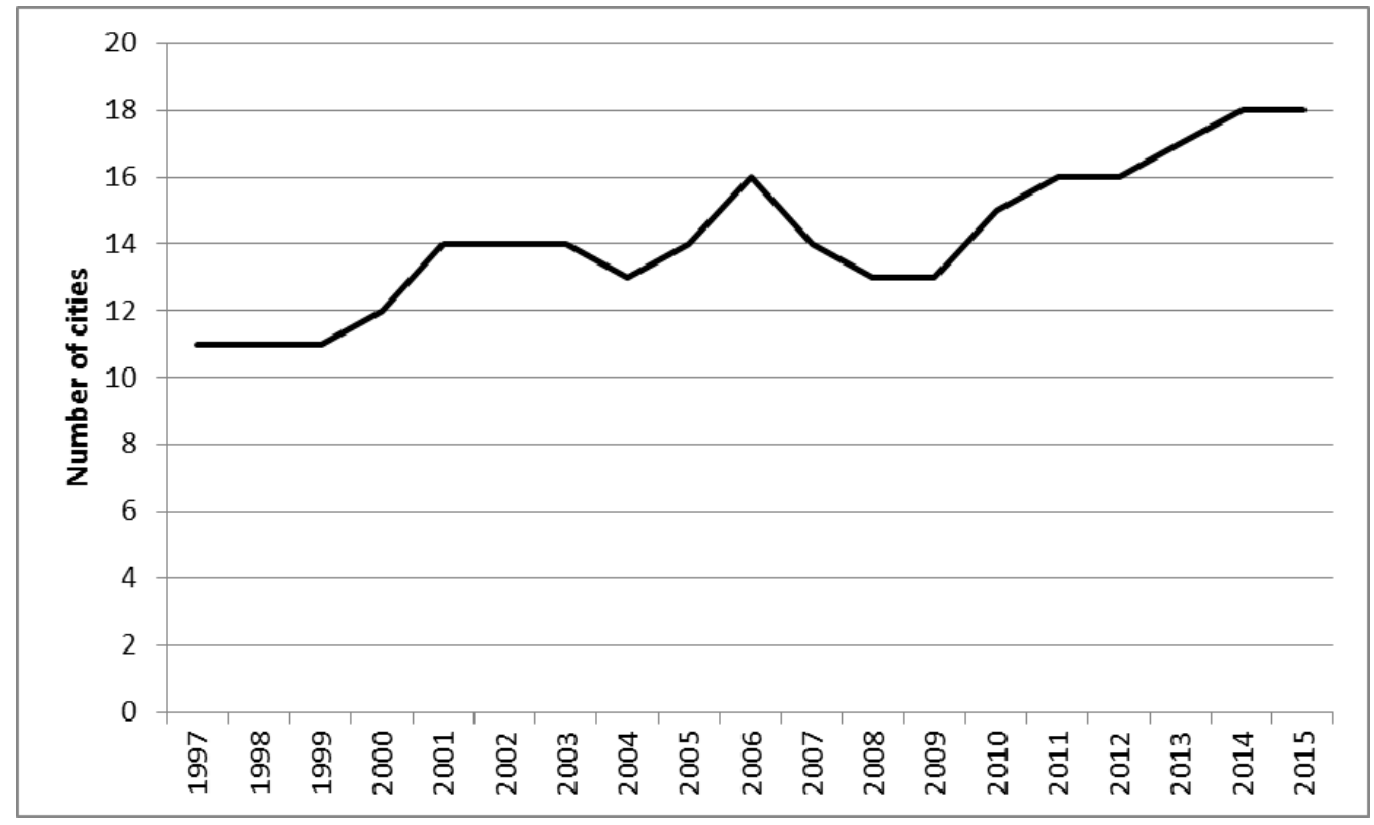

Fig. 1 - The expansion of the number of cities which provided the level of master studies (source: own elaboration based on the database from CVTISR)

\section{Methods and material}

The examined sample was represented by all graduates of the master studies (including both forms of study - internal and external), and by all universities and colleges (public, private and state), that were operating in Slovak cities. These graduates were sorted by fields of studies. The observed time period accounted for years 1997 to 2015 . The examined objects were 20 cities in which were located individual faculties of universities and colleges that were producing graduates of the master level studies.

Data on the number of graduates of master studies, by all universities operating in Slovak cities, were from the databases of Centre for Scientific and Technical Information of the Slovak Republic (CVTISR), what is an organization set up by the Ministry of Education, Science and Research of the Slovak Republic. The research was taken on 46 fields of studies for master studies. For better and clearer results, 41 fields of studies were aggregated into four different groups of studies. First group of studies represented 6 fields of studies of natural sciences, second group of studies represented 17 fields of studies of technical sciences, third group represented three fields of studies of medical sciences and fourth group of studies represented 15 fields of studies of human sciences. Five fields of studies were excluded due to incomplete data.

For examination of the development of concentration, respectively dispersion of the production of graduates of master studies between Slovak cities, was used the Herfindahl-Hirschman index.

The formula of Herfindahl-Hirschman index:

$$
H H I=\sum_{i=1}^{N} S^{2}
$$

where the letter $S$ is representing the proportion of graduates in the i-th city of the total number of graduates in the reference year. Observed cities could take the index value in range from 0 to 1 . Values closer to 0 means a dispersion of graduates and a high competition between cities in production of graduates, while values closer to 1 means a concentration of graduates and monopolization between cities in production of graduates. 


\section{Results}

The evolution of overall number of university graduates, observed in all 41 fields of studies with the evolution of Herfindahl-Hirschman index can be seen in Figure 2.

Figure 2 shows that the total number of graduates of master studies increased from the initial reference year 1997 up to 2011, when successfully completed their master studies most students (32 501 graduates). From the evolution of the $\mathrm{HHI}$ values, the Figures shows that the highest value (0.21) was in the initial reference year. The obtained value means, that in 1997, the competition among cities in producing graduates of master studies was the lowest. The lowest level of HHI score (0.17) was in 2007. It means that in 2007, the competition in production of graduates of master studies between Slovak cities was the highest. In 1997, there were 16 colleges and universities producing graduates of master studies located inside 11 cities.

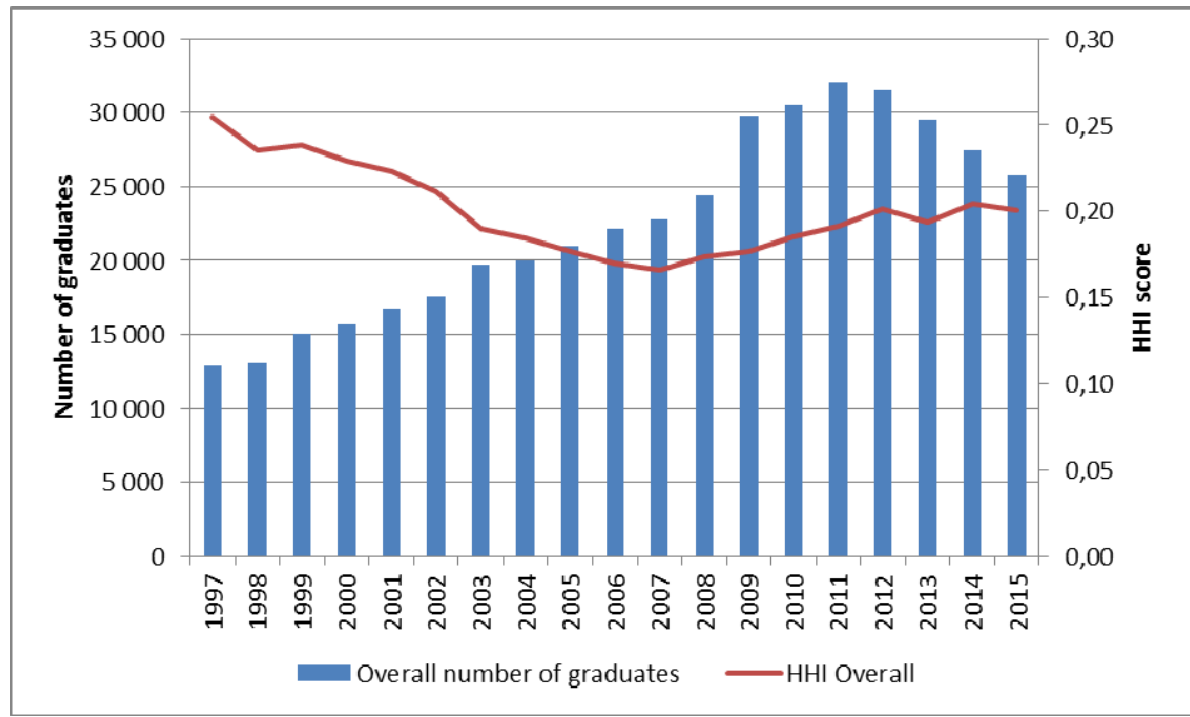

Fig. 2 - Overall evolution of number of graduates (source: own elaboration based on the database from CVTISR)

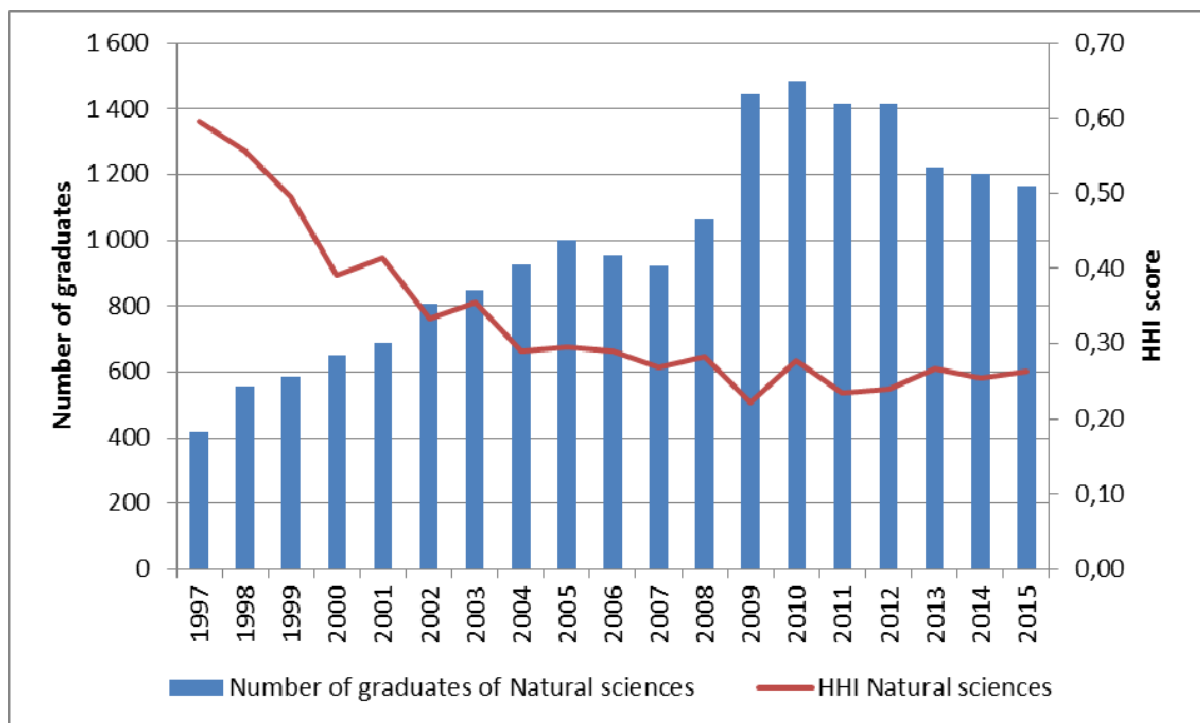

Fig. 3 - Number of graduates in natural sciences (source: own elaboration based on the database from CVTISR) 
In 1997, 45 percent of all graduates were produced in Bratislava. On the other hand, only 1 percent of all graduates successfully completed their master studies in Martin. In 2015, inside 18 Slovak cities (except Badín and Spišské Podhradie) were located 34 colleges and universities that produced graduates of master studies. The largest share of graduates came from Bratislava (39 percent), and the tiniest share came from Komárno (1 percent).

Figure 3 shows that the number of graduates of master studies from the group of natural sciences grew from 1997 to 2005. In 2010, 1483 graduates of master studies successfully completed their studies. It was the biggest increment during the observed time period. From the perspective of the evolution of the $\mathrm{HHI}$ values, the Figure shows that the highest value (0.59) was in the initial index reference year. The value means that in 1997 the competition among the production of graduates between Slovak cities was the lowest. The lowest value of $\mathrm{HHI}$ score $(0.22)$ was in 2009. In this year the competition between Slovak cities was the highest. In 1997, only 3 colleges and universities were located in 3 cities (Bratislava, Košice, Zvolen), which were producing graduates of master studies. In this year, 75 percent of all graduates of natural sciences came from Bratislava. On the other hand, only 12 percent of the total number of all graduates came from Košice. In the last reporting year, 11 colleges and universities were located in 8 cities. The largest share of graduates of master studies was produced in Bratislava (44 percent), while the lowest proportion was produced in Trnava (2 percent).

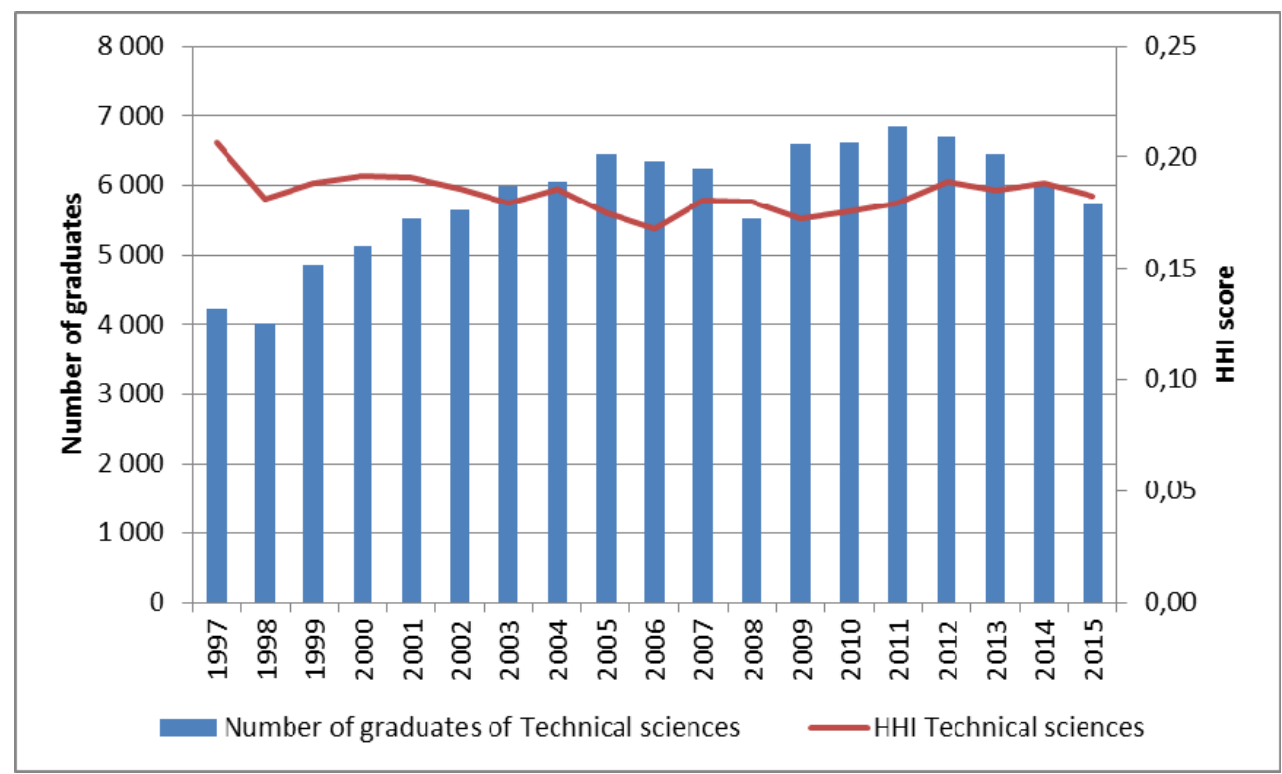

Fig. 4 - Number of graduates in Technical sciences (source: own elaboration based on database from CVTISR)

Figure 4 shows the evolution of the number of graduates of master studies of technical sciences as well as the values of Herfindahl-Hirschman index. The number of graduates of technical sciences has grown from 1997 up to 2005, then from 2009 to 2011. In 2011, 6854 graduates of master studies successfully completed their studies. The evolution curve of the $\mathrm{HHI}$ values indicates that the highest value $(0.21)$ was in
1997. In this year the competition among Slovak cities in production of graduates of master studies in technical sciences was the lowest. The lowest value of $\mathrm{HHI}$ score (0.17) was in 2006. In this year, the competition in production of graduates was between Slovak cities the highest. In 1997, only 7 universities in 7 cities produced graduates of master studies in technical sciences. In this year, 26 percent of all graduates 
successfully graduated in Bratislava. On the other side, only 1 percent of all graduates of technical sciences successfully graduated in Prešov. In 2015, the last reporting year, 12 colleges and universities in 11 cities were producing graduates of master studies in technical sciences. The largest share of graduates came out from Bratislava and Košice (both with 25 percent) and the tiniest share of graduates came out from Banská Bystrica and Púchov (both only with 1 percent).

The evolution of the number of graduates of master studies in medical sciences with the evolution of the values of $\mathrm{HHI}$ can be seen on Figure 5. During the observed time period, the evolution of both curves was very turbulent.

The number of graduates of master studies in medical sciences stagnated from 1998 to 2007. In 2007 there was a significant increment of the number of graduates. The biggest increment of the number of graduates of master studies in medical sciences was in 2009. In this year, 3215 graduates successfully completed their master studies. From the perspective of the evolution of $\mathrm{HHI}$ values, the Figure shows that the highest value (0.47) was reached in 2010. That means, in 2010 the competition in production of graduates of master studies in medical sciences was between Slovak cities the lowest. The lowest value (0.25) of HHI was in 2007. In this year, the competition between Slovak cities was the highest. In 1997 only 3 colleges and universities in 4 cities (Bratislava, Košice, Martin, Trnava) produced graduates of master studies in medical sciences. In 1997, 47 percent of all graduates came from Bratislava. On the other side, only 2 percent of all graduates came from Trnava. In 2015, there were 7 universities in 9 cities producing graduates of master studies. The largest share of graduates came out from Bratislava (67 percent), and the lowest share came out from Košice and Martin (both only with 1 percent).

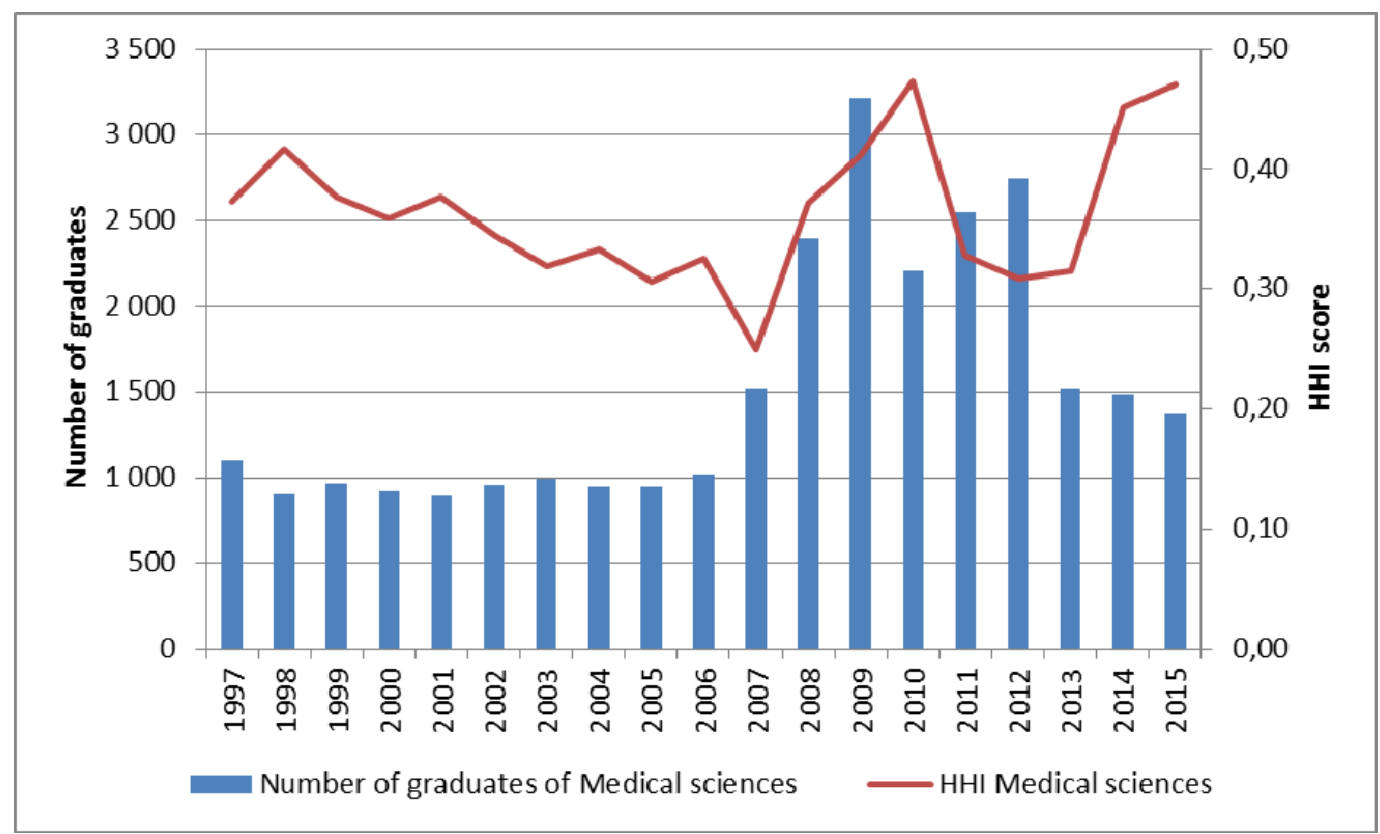

Fig. 5 - Number of graduates in Medical sciences (source: own elaboration based on the database from CVTISR)

Figure 6 shows that the number of graduates in human sciences increased from the initial reference year up to the year 2011. In 2011, 21 235 graduates successfully completed their master studies in human sciences. From the evolu- tion of $\mathrm{HHI}$ values the Figure 6 shows, that in 1997 the value was the highest (0.33). That means, in 1997 the competition between Slovak cities in production of graduates of master studies in human sciences was the lowest. The low- 
est vale of HHI score (0.18) was recorded in 2009. That means, in this year the competition between Slovak cities in production of graduates was the highest. In 1997, there were 11 colleges and universities in 9 cities that were producing graduates of master studies in human sciences. In 1997, 53 percent of all graduates successfully completed their master studies in Bratislava and only 2 per- cent from the total number graduated in Trnava. In 2015, 11 colleges and universities in 15 cities were producing graduates of master studies in human sciences. The largest share of graduates came out from Bratislava (42 percent) and the tiniest share came out from Zvolen (only 1 percent).

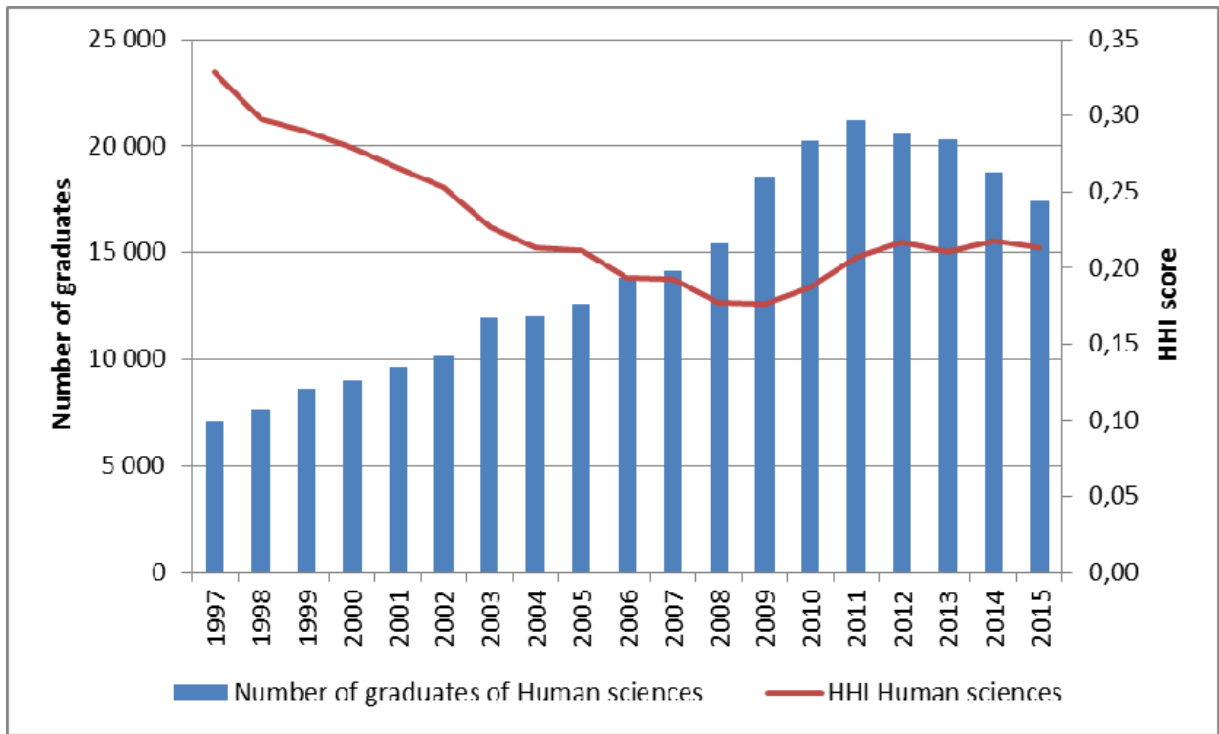

Fig. 6 - Number of graduates in Human sciences (source: own elaboration based on the database from CVTISR)

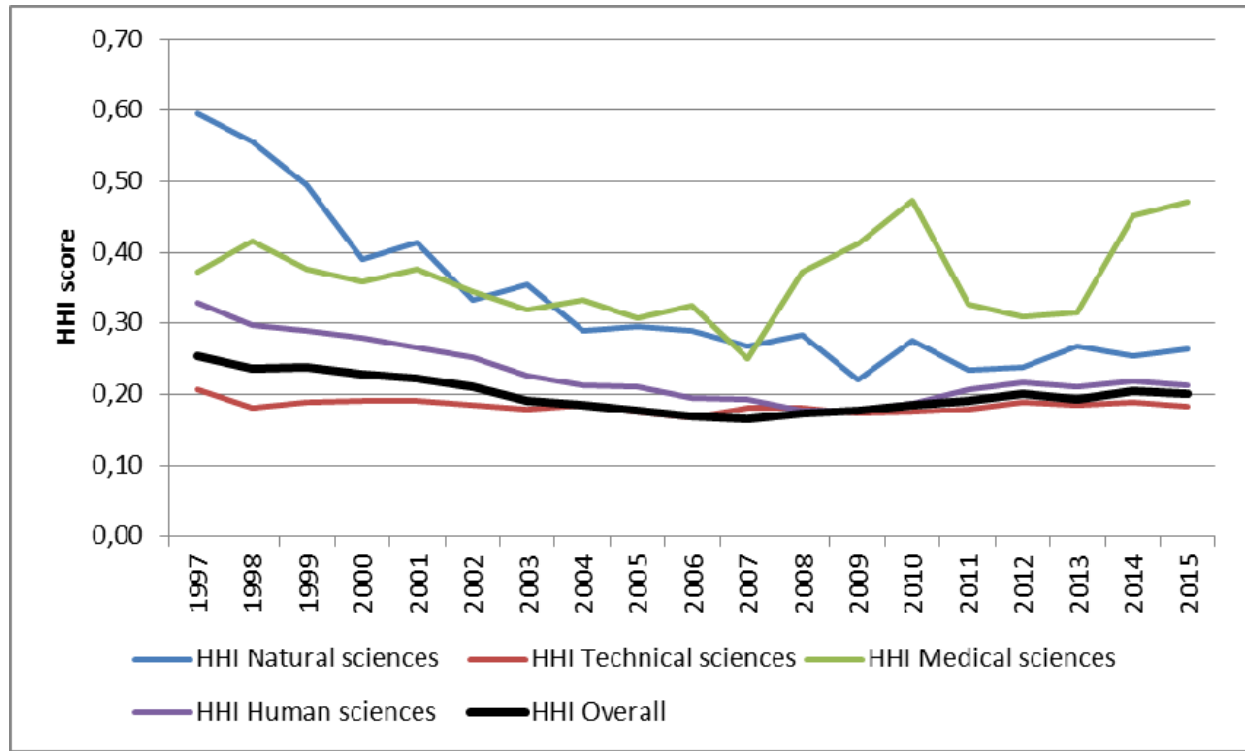

Fig. 7 - Number of graduates in Overall evolutions of $\mathbf{H H I}$ scores (source: own elaboration based on the database from CVTISR) 
Figure 7 shows and overview of the evolution of all $\mathrm{HHI}$ indices. From the overall point of view, the competition in producing graduates of master studies between Slovak cities has during the observed time period increased. The decline of overall HHI values from 1997 (0.25) to 2015 $(0.20)$ on the Figure, is represented by the black curve. During the observed time period, there has been a dispersion of production graduates of master studies, which is represented by the increment of cities that were producing graduates. In 1997, there were 16 colleges and universities located in 11 cities, while in 2015, there were 34 colleges and universities located in 18 cities. Increased competition in the production of graduates of master studies took place between Slovak cities that were producing graduates from natural sciences, technical sciences and human sciences. The evolution of their HHI values on the Figure 7 proves that. Reduced competition was recorded between cities in production of graduates of master studies in medical sciences. The green curve of $\mathrm{HHI}$ values for medical sciences proves that. In 1997 the value of $\mathrm{HHI}$ was 0.37 , but in 2015 it was 0.47 .

\section{Discussion}

In the context of the creation of human capital as a factor, which supports socio-economic development and the allocation of space to achieve balanced regional development, it is appropriate that the production of university graduates (as holders of high human capital) is dispersed in territory. The obtained values of $\mathrm{HHI}$ for all graduates of master studies shows that in observed time period in Slovakia it occurred a dispersion of production of graduates. The balance in the production of graduates also occurred in production of graduates of master studies of natural sciences, technical sciences and human sciences. On the other hand, the concentration of production occurred in the studies of medical sciences. From the perspective of $\mathrm{HHI}$ values it can be said, that the monopolization of production of graduates in master studies in medical sciences probably will not help in the balanced development of cities and regions of Slovakia, while the increased competition in production of graduates of other studies could contribute to more balanced development. Therefore the decision makers should create and implement policies that would respect differences in regional production of human capital.

\section{Conclusions}

The aim of this contribution was to examine the evolution of graduates of universities and colleges in Slovak cities and check their production concentration of dispersion. The results mentioned above showed, that during the observed time period the overall concentration of production of graduates has reduced, and therefore the competition between cities in production of human capital has increased. A significant shortcoming of this contribution lies in the absence of migration of graduates. In the absence of data on the final localization of graduates it cannot be determined how much of the production of graduates remain in the city and thus it cannot be told, where there was an increase or decrease in supply of high human capital, which is a prerequisite for creating city or regional development. But, the awareness of this and other shortcomings gives some ideas for continuing to examine this issue. Major ideas and recommendations for decision makers from this paper could be summarized in these three key points:

- To achieve balanced regional development in Slovakia, focusing on the factor of human capital, it is necessary to continue in the diversification of the production of university and college graduates in the country.

- It is important to look at every single region independently, and consider carefully implementing same development or innovation policies, because the structure of graduates can be different.

- To obtain deeper analysis, it is essential to start to collect data on the migration of university graduates. This type of information will provide much better overview on regional specialization and regional needs in terms of human capital, 
usefulness of some regions in terms of supplying other regions with specific human capital and the importance of establishing some new, specific universities and colleges in concrete regions or close those that are useless.

\section{Notes}

${ }^{1}$ Badín is a village, but for the purposes of this contribution, it is considered as a city.

\section{Acknowledgements}

This work was supported by the Slovak Research and Development Agency under the contract No. APVV-14-0512

\section{References}

Benneworth P, Charles D, Madanipour A (2010) Building Localized Interactions Between Universities and Cities Through University Spatial Development. European planning studies 18: 1611-1629.

Centre for Scientific and Technical Information of the Slovak Republic (CVTISR) The origin of used data was from the intern database of the Centre. [6.4.2016]. Available contact at: <http://www.cvtisr.sk/sk/ kontakty.html?page_id=398>

Goddard J, Vallance P (2013) The University and the City (Regions and Cities) in Regional Studies Association. Routledge, Taylor \& Francis Group, London.

Goldstein H, Bergman EM, Maier G (2011) University mission creep? Comparing EU and US faculty views of university involvement in regional economic development and commercialization. The Annals of Regional Science 50: 453-477.

Hansen JA, Lehman M (2006) Agents of change: universities as development hubs. Journal of Cleaner Production 14: 820-829.

Huggins R, Johnston A (2009) The economic and innovation contribution of universities: a regional perspective. Environment and Planning C: Government and Policy 27: 1088-1106.

Karlsson CH, Zhang WB (2001) The role of universities in regional development - Endogenous human capital and growth in a two-region model. The Annals of Regional Science 35: 179-197.

Rehák Š, Džupka P, Šebová M, Sekelský L (2015) Lokálne ekonomické vplyvy univerzít. Vydavatel'stvo EKONÓM, Bratislava.
Scott JC (2006) The Mission of the University: Medieval to Postmodern Transformations. The Journal of Higher Education 77: 1-39. 